This is an Accepted Manuscript of an article published by Taylor \& Francis Group in

Community, Work \& Family on 01/09/2020, available online:

https://doi.org/10.1080/13668803.2020.1809995

The article is part of the SHARE project, which has received funding from the European

Research Council (ERC) under the European Union's Horizon 2020 research and innovation programme (Grant agreement No. 715950).

\title{
Work-Family Conflict in Europe. A focus on the Heterogeneity of Self-employment
}

\author{
Rossella Bozzon, University of Milan (rossella.bozzon@unimi.it) \\ Annalisa Murgia, University of Milan (annalisa.murgia@unimi.it)
}

\begin{abstract}
This article aims at analysing how subjective work-family conflict is experienced by different self-employed men and women in comparison to employees and informal workers in Europe. Firstly, it focuses on how job-related resources and demands characterise traditional and emerging types of self-employment affecting the perception of work-family conflict. Secondly, it explores both gender-related institutional and societal dimensions, by analysing how the conflict is differently mediated by reconciliation policies and by the degree of gender equality in society. Based on the 6th European Working Condition Survey, findings show that self-employment is a hybrid area of work which, depending on its characteristics, can be more similar to entrepreneurial, dependent or informal work. As for the work-family conflict, the study indicates that self-employment can only mitigate it in the case of 'dependent selfemployment', a work arrangement which, however, while facilitating the reconciliation of work and family, poses significant problems in terms of quality of the working time, especially in the case of women. Genuine forms of selfemployment seem instead to represent a source of conflict, and to suffer the lack of gender equality in different European societies and labour markets.
\end{abstract}

Keywords: Self-employment, work-family conflict, job-related demands and resources, institutional and societal factors 


\section{Introduction}

Labour market transformations and the emergence of new work arrangements that blur the boundaries between employment and self-employment are challenging work and life equilibria as well as how men and women reconcile their professional and private lives.

Within the debate about the transformation of employment relations, the growth of selfemployment has raised a discussion about how to define self-employed jobs and classify them. Scholars detect a polarization process of self-employment, which ranges from entrepreneurs and 'stable' solo self-employed to 'vulnerable' and 'concealed' selfemployed workers (Eurofound, 2017). On the one hand, self-employment can correspond to positions that provide workers with more autonomy and control over tasks and time, and with a higher quality of work. On the other hand, the increase of self-employment is also seen as a consequence of rationalization and marginalization processes, which favour the development of forced and weak autonomous job positions hiding vulnerable (and economically dependent) self-employment relations (Smeaton, 2003). These latter positions substantially differ from traditional self-employment characterised by a genuine entrepreneurial ethos (Dekker, 2010; Smeaton, 2003). Selfemployment thus becomes a hybrid area of work, which contains a wide spectrum of positions, ranging from 'genuine' to 'dependent' self-employed workers, who are formally described as self-employed but possess the characteristics of wage workers since they do not have employees, economic autonomy, and authority and/or control over how to run their businesses (Eurofound, 2017).

Despite the consolidation of new ways of classifying self-employed workers, how work-family conflict is differently perceived by the various categories of self-employed, compared to traditional typical entrepreneurs, employees and informal workers, is still 
overlooked in the academic debate. Moreover, available studies on the work-family conflict of the self-employed show contrasting evidence. Comparing studies on subjective work-family conflict is problematic because of the extreme variation in the analytical design and in the measurement of conflict (Kossek \& Lee, 2017). However, the divergent results for the self-employed are mainly connected to two aspects. Firstly, these studies tend to underestimate the heterogeneity of positions within selfemployment. Self-employed workers are, in fact, analysed as a single group or simply divided considering the presence (or absence) of employees (Annink, den Dulk, \& Steijn, 2016; Hagqvist, Toivanen, \& Bernhard-Oettel, 2018; König \& Cesinger, 2015; Nordenmark, Vinberg, \& Strandh, 2012; Reynolds \& Renzulli, 2005). Secondly, contrasting results are connected with macro gender-related institutional and societal dimensions, which moderate the experiences of work-family conflict for both women and men (self-)employed in different societies (Abendroth \& den Dulk, 2011; Fahlén, 2014; Hagqvist et al., 2018; Powell, Francesco, \& Ling, 2009).

The aim of this contribution is to enhance our understanding on how different types of self-employed men and women differ in their perception of work-family conflict, and how their perception changes across national gender-related institutional and societal equilibria. Therefore, firstly, this study explores how different types of self-employed workers perceive work-family conflict in comparison with employees - both permanent and fixed-term - and informal workers. Based on a Job Demands-Resources (JD-R) approach (see Kossek \& Lee, 2017; Schieman, Milkie, \& Glavin, 2009), how this conflict is mediated by a different distribution of job-related demands and resources is analysed. The second main aim is to understand whether differences in work-family conflict across self-employed types are related to relevant institutional and societal gender-related factors. This means to explore how family and work-life balance 
policies, on the one side, and gender norms and gender equality gaps in the labour market, on the other, differently affect the subjective work-family conflict of different types of self-employed workers.

This article is structured as follows. We firstly introduce how the JD-R theoretical framework can be applied to the case of self-employment. It follows a section devoted to how differences in gender equality achievements across European countries affect the perception of work-family conflict, with a focus both on institutional and societal dimensions. After a description of the data sample and variables, we present the results of: (i) a descriptive analysis of the job-related demands and resources profile by work arrangement for men and women; (ii) the perception of work-family conflict across different types of self-employment, employment and informal work, and the effects of JD-R; and (iii) an analysis of how macro structural and cultural features at country level moderate the experience of conflict of the self-employed in comparison to other workers.

\section{Theoretical background}

\section{Self-employment and work-family conflict in the JD-R framework}

Much of the literature on work-family conflict is based on the JD-R perspective.

Grounded in role theory (Goode, 1960), this approach identifies specific occupational conditions that either contribute to difficulties or to solve problems in work-family balance (Kossek \& Lee, 2017). Job demands are job requirements related to physical and/or mental efforts - such as long working hours, emotional and cognitive efforts, high work intensity, time pressure to accomplish job goals, and job uncertainties which subtract energies from other life spheres. Job resources are factors that support 
workers to cope with job demands, such as forms of autonomy and control of working time schedule (flexibility), job tasks, pace of work and method of work. Theoretical arguments suggest that different forms of job autonomy and control tend to reduce pressure by giving workers greater control over their schedule, pace, and work organisation, with positive consequences on the levels of subjective work-family conflict. Conflict occurs when certain job-related resources are lacking and/or different demands (from both job and household) exceed a certain level (Bianchi \& Milkie, 2010). Typically, high work intensity, time pressure, low job control on schedule and job tasks increase the perception of conflict (Gallie \& Russell, 2009).

Scholars have different theories about how self-employment affects the relationship between job-related demands and resources and work-family conflict. (König \& Cesinger, 2015; Nordenmark et al., 2012; Russell, O’Connell, \& McGinnity, 2009; Schieman et al., 2009).

Part of the literature tends to identify self-employment as a job resource and claims that it may offer autonomy and flexibility, especially to women, allowing them to overcome barriers and discrimination in standard employment relations, increase the level of job autonomy and control, and achieve a better balance between work and family duties (Annink \& den Dulk, 2012; Parasuraman \& Simmers, 2001; Reynolds \& Renzulli, 2005). From this perspective, self-employment can be seen as a way to be easily included in paid labour, and to enjoy high working time flexibility, to break free from bureaucratic control, and to decide when, where, and how to work (Reynolds \& Renzulli, 2005). Temporal and physical flexibility and autonomy, in fact, determine how permeable role boundaries are, and thus to what extent work and life activities can be integrated or segmented. According to this perspective, self-employment is especially attractive for women to limit employer discrimination and improve the 
reconciliation of work and family. Several empirical studies show that flexibility and autonomy are the primary motivations for women for opting for self-employment, while men seem to be more sensitive to economic issues, such as income gains and the need to sustain their socially prescribed role of breadwinner (Georgellis \& Wall, 2005). Reynolds and Renzulli (2005) also show, in the US context, that the opportunity of working from home can reduce work-family conflict, and that temporal flexibility and autonomy are able to prevent work roles from interfering with life roles. Moreover, they find that because women experience a higher increase in control than men, when they move from a dependent to a self-employed position, self-employment has more benefits for women than for men. König and Cesinger (2015) show instead that working time flexibility and job autonomy, in the case of self-employed workers in Germany, contribute to a reduction in time-based work-family conflict, but have no effect on strain-based work-family conflict, which is higher than among employees.

Within the JD-R debate, there are also scholars who state that the positive roles of autonomy and control are overestimated and that high levels of job autonomy and flexibility in self-employment do not necessarily decrease work-family conflict, but may rather prevent a good work-life balance. In this regard, Schieman and colleagues (2009) proposed the 'stress of higher status' argument. This perspective focuses on the role of job-related demands and claims that self-employment may imply a higher job involvement and time commitment, which can fuel the conflict between work and family (Annink \& den Dulk, 2012; Annink et al., 2016; Gallie \& Russell, 2009; König \& Cesinger, 2015; Parasuraman \& Simmers, 2001). Working conditions of the selfemployed are in fact often characterised by a high workload and working hours per week than the average of employees (Hagqvist, Toivanen \& Vinberg, 2015). Therefore, job-resources usually related to self-employment - e.g. autonomy, discretion in 
organising work, and schedule control - are not enough to contrast the negative effect of job demands. Self-employment is thus more likely to invade all other spheres of life resulting in blurred temporal, spatial and mental boundaries that increase work-family conflict (Hilbrecht \& Lero, 2014).

The growing heterogeneity within self-employment leads to the question of which scenario prevails for different types of self-employment. If the approach that stresses the role of job-resources prevails, the self-employed more similar to employees should experience a high level of work-family conflict because they do not have the real advantage from the flexibility, control and autonomy that a genuine self-employed worker is supposed to have. On the contrary, according to the perspective that stresses the role of job-demands, the 'genuine self-employed' should be the category that perceives the highest level of work-family conflict for the difficulty in controlling the boundaries between work and other life domains.

\section{Contextualising subjective work-family conflict: The role of gender related institutional and societal conditions}

The individual experiences of work-family conflict are institutionally embedded (Abendroth \& den Dulk, 2011; Fahlén, 2014; Powell et al., 2009). Cross-country comparisons consistently reveal differences in the levels of work-family conflict that cannot be explained by micro factors, but are connected to macro institutional and societal features that modulate, relieve or enhance individual experiences of conflict.

Scholars agree that gender egalitarianism (Powell et al., 2009) is a crucial dimension that shapes men and women experiences of conflict. Gender-related institutional and societal factors influence the access of men and women to labour market and the division of paid and unpaid work, as well as how male and female roles are expressed 
and accepted in the public and the private spheres (Fahlén,2014; Kossek \& Lee, 2017; Ollier-Malaterre \& Foucreault, 2016; Powell, et al., 2009).

Empirical studies provide contradictory evidences about the role and prevalence of gender-related institutional and societal features on how men and women perceive work-family conflict. Part of the literature shows that availability of work-life balance policies (parental leaves, children's and elderly care services, flexible work arrangements), as well as the prevalence of gender-equality in society, allow to relieve tensions in work-family balance and favour labour market integration of men and women over the life course (Chung, 2011; Kossek \& Lee, 2017; Ollier-Malaterre \& Foucreault, 2016). Other scholars argue instead that extensive family policies (Cousins \& Tang, 2004) and progressive or egalitarian gender cultures (Ruppanner \& Huffman, 2014; Steiber, 2009; van der Lippe, Jager, \& Kops, 2006) enhance the pressures that come from the private sphere favouring higher perceptions of work-family conflict than traditional gender contexts.

Despite these diverging positions, a common limit of these works is that they assume that the consequences of gender related institutional and societal features are homogeneous for men and women in different types of work arrangements. But, on the one side, institutional factors - such as such as the availability of social and reconciliation policies - as well as the availability of flexible work arrangements, relate differently to standard, non-standard, informal and self-employed workers (Buschoff \& Schmidt, 2009). On the other, gender norms and different gender-equilibria in society and in the labour market can produce different consequences according to the gender culture and norms within which the different types of work arrangements are framed. In particular, in this work we want to understand how institutional and societal genderrelated factors moderate the subjective work-family conflict for different types of work 
arrangements, from self-employment to dependent employment and informal work.

Firstly, we expect that gender related institutional features, i.e. the availability of worklife balance policies may affect subjective conflict only of workers with standard employment positions, but may have limited effects on men and women in non-standard positions, self-employment and informal economy. Secondly, in the case of societal factors, we expect that the self-employed in gender traditional contexts should face more difficulties in reconciling their private and working life than all other working arrangements, and compared to the self-employed who live in more egalitarian countries. For women, this should happen because they find themselves in contexts that favour traditional gender roles occupying traditional men's jobs where masculine norms and practices prevail, exacerbating the work-related pressures and fuelling the perception of work-family conflict (Bruni A, Gherardi S, \& Poggio B, 2004; Gherardi \& Poggio, 2018). In the case of men, this happens because in traditional context men are expected to be more focused on objective material success (Powell et al., 2009), and self-employed positions are more exposed to high economic instability and to business uncertainties than employees.

\section{Data and variables}

This analysis is based on the European Working Conditions Survey (EWCS) 2015 (Eurofound, 2018). The dataset includes variables that allow to: i) measure subjective work-family conflict; ii) measure JD-R dimensions; iii) classify self-employed

positions, distinguishing between self-employed with employees, 'genuine' and 'dependent' solo self-employed (SSE) workers. The dataset was then integrated with four country-specific indexes that account for contextual differences in institutional and 
societal gender equality. Furthermore, we added the family policies index, the labour market structure index, and the gender norms index, as well as the gender gap index in the labour market. The macro indicators are all available for all the EU27 countries. The final sample includes 15,838 men and 16,480 women aged 15-74 who reported having a job at the time of the interview.

Subjective work-family conflict is usually studied from two perspectives: from work to family and from family to work. In this work we focus only on the first direction. This is because, according to the key literature on subjective work-family conflict (see Kossek \& Lee, 2017), changes in organisation and forms of work affect the subjective conflict that flows from work to family, while family to work conflict is more connected with changes in the private sphere. Thus, the main measure used in this work is an additive standardized index ( mean $=0, \mathrm{sd}=1$ ) of subjective work to family conflict based on three items measured on a five-point scale of how often respondents have perceived time-based (found that their job prevented them from giving the time they wanted to their family), and strain-based (kept worrying about work when they were not working, and have felt too tired after work to do some of the household activities that need to be done) tensions between work and family spheres in the last twelve months (Conbach's Alpha = 0.69). Fig. 1 summarises the average level of the work-to-family conflict index by work arrangements for men and women.

At the individual level, the main factors under examination are work arrangements, job demands and job resources. Work arrangements are distinguished between dependent employment (permanent or fixed-term), informal work (no employment contract), and self-employment (with and without employees). Among the SSE - who do not have employees - we further differentiate between 'genuine' and 'dependent' (Eurofound, 2017; Williams \& Horodnic, 2018). More precisely, dependent SSE have at least two of 
these three characteristics: only work for one client (or more than $75 \%$ of their income comes from the same client); do not have the authority to hire staff if necessary; do not have the authority to make important strategic decisions about how to run their business.

Within the frame of the JD-R approach, a set of indicators was identified. As job-related demands, we considered: working time demands (weekly working hours and a standardized index of quality of working hours - i.e. working unsocial hours, overtime, in free time and/or at short notice); standardize indexes of job pressures such as pace, emotional and cognitive demands. As job-related resources, we considered: dummy indicators on job discretion on tasks, methods and the speed of work; a standardize index of the level of job autonomy (i.e. influence the decision at apply own ideas at work, contribute to improve the organization of work); categorical variable of the level of control over the working time schedule (working time arrangement) and over the place of work (work from home); and the weekly-time spent commuting from home to work. Moreover, as a proxy of monetary resources, we used a dummy indicator of selfperception of being well-paid, and as a proxy of job security we used the perceived risk of losing a job in the next six months (1=disagree, strongly disagree) and the job skill level (ISCO 1000, 2000 and 3000). The appendix contains a detailed description of the variables included in the analyses and the main descriptive statistics for men and women.

Focusing on the private sphere, as measures of household composition and care duties we considered three dummy variables that identify who lives with a partner, has dependent children (aged 0-15) in the household, and cares for children, grandchildren, elderly or disabled relatives daily or several times a week. As proxy of the household economic situation, we used a dummy measure of subjective income insecurity of the 
household, which identifies who answered that their household income was able to make ends meet 'with difficulty' or 'with great difficulty'. As socio-demographic characteristics we considered age and level of education.

At country level, we included in the dataset four macro indicators with the aim of capturing differences in gender-related institutional and societal features for 27 countries. Three indicators are derived from the work of Matysiak and WęziakBiałowolska (2016), who have developed a comprehensive index of country-specific conditions for work and family reconciliation. In particular, we included: the family policies index which captures country differences in the availability and quality of childcare services and parental leave; the labour market structure index, which captures country differences on the labour market related to work-life balance policies such as flexibility of working-hours (availability and quality of part-time work) and barriers to labour market access (employment protection legislation); the gender norms index, which seizes norms regarding the gender division of unpaid and paid work, and the social acceptance of mothers' employment as well as fathers' involvement in childcare. It is based on gender norm items included in the European Value Survey. The three indexes range from 0 to 100 .

Finally, we considered a measure to catch the actual gender equality situation in the national labour market. With the aim to measure gender equality in working life across countries, we also used the economic participation and opportunity section of the global gender gap index (Hagqvist et al., 2018). This index comprises three areas: the participation gap - the ratio of women's labour force participation to men's labour force participation; the remuneration gap - the wage equity between men and women for similar work; and the advancement gap - the ratio of women to men among legislators, senior officials and managers, and technical and professional workers. A value of one 
on the global gender gap index signifies perfect equality, whereas zero indicates the highest level of inequality. All four indexes are presented in the Appendix.

\section{Findings}

\section{Self-employment types and job-related resources and demands}

Before deepening the relation between work arrangements - employment, selfemployment, informal work - and subjective work-family conflict, this section briefly describes the main differences between the three types of self-employment - selfemployed with employees, 'genuine' and 'dependent' SSE - according to the main indicators of job-related resources (Table 1) and job-related demands (Table 2) considered in the analysis, as well as how they differ from wage and informal job positions. This highlights significant differences between the self-employed with employees and genuine SSE, on the one side, and the dependent SSE, on the other. Dependent SSE have a profile in many respects positioned halfway between the selfemployed and the employees.

\footnotetext{
***Table 1 and Table 2 about here***
}

On average, all types of self-employment offer a higher degree of freedom in terms of how, when and where to work in comparison to employees and informal workers. Jobrelated resources associated with self-employment, such as job autonomy and discretion, are generally widely available among all types of the self-employed. Even though for dependent SSE the level of resources is more limited, they do still experience levels of autonomy and control higher than employees and informal workers. Especially SSE women are in positions associated with an extremely high degree of control over their working schedule and working place. This is consistent with the literature that 
identifies the greater margins of control over times and places of work as the main driver that pushes especially self-employed women to enter in these positions (Georgellis \& Wall, 2005; Hilbrecht \& Lero, 2014).

The higher levels of control, autonomy and discretion experienced by the self-employed are balanced by higher levels of job demands, mainly time-related (Hagqvist et al., 2015). The self-employed usually work more hours per week than employees - both fixed-term and with an open-ended contract - and informal workers, and the quality of their working schedule is particularly low. All the self-employed work unsocial hours more often than employees. While the self-employed with employees and genuine SSE experience the most time-demanding work arrangements, dependent SSE are the type of self-employment that experiences shorter weekly working times - with an average number of working hours similar to employees. However, different from other work arrangements, dependent SSE experience a polarization between part-time (working fewer than 25 hours per week) and over-time (working more than 45 hours per week), suggesting a wide differentiation in working-time conditions within this category of SSE. Moreover, differently from other self-employment types, dependent SSE occupy job positions with lower time-demands and, at the same time, the quality of their working time is lower than that of employees. Therefore, dependent SSE positions seem to allow management and limiting of the volume of hours worked per week, but with no real advantage on the quality of working schedules, especially in the case of women.

\section{Self-employment and work-family conflict: The role of job demands and resources}

Moving to the core of our contribution, which aims to understand how work-family conflict is perceived by different groups of self-employed workers, figure 1 shows the 
distribution of the work-family conflict index by work arrangements and by gender in Europe. On a descriptive base, self-employed workers experience a higher level of conflict than employees and informal workers. However, there are significative differences across the different self-employment types. Self-employed with employees and genuine SSE register the highest level of conflict, while dependent SSE experience a mean level of conflict closed to the population average (i.e. reference line equal to 0 on y axes). More specifically, in the case of women, dependent SSE perceive similar levels of conflict than employees with open-ended and fixed-term contracts. Among men, even if the subjective conflict progressively decreases moving from self-employed with employees to dependent SSE, the average conflict is always significantly higher than for employees (both permanent and fixed-term) and informal workers.

$$
\text { ***Figure } 1 \text { about here } * * *
$$

To detect whether and how the differences in subjective work-family conflict shown in Figure1 are mediated by individual and household characteristics and job resources and demands, we estimated four multilevel models for individuals nested in countries. Since we suppose that job-related demands and resources, as well as household situations, play different roles for men and women, we estimated separate models by sex.

Table 3 shows the estimated models that analyse the differences across work arrangements in the level of subjective work-family conflict controlling for three groups of variables: i) household and socio-demographic characteristics; ii) job-related resources; iii) job-related demands. 
Model M1, which controls for work arrangement, household and individual characteristics, presents the differences across self-employment types, employment and informal work, and in subjective work-family conflict, as displayed in Figure 1.

Models M2, M3, M4 confirm that the job-related demands associated with selfemployed positions are key to explaining the greater conflict among the self-employed, as well as the higher economic commitment in running their business that defines genuine forms of self-employment. The typical resources of self-employment including greater autonomy and discretion in organising their daily job - seem to have a limited role in counterbalancing the pressures of job demands and, as in the case of working from home, rather increases the conflict.

In the case of men, controlling for job related demands and resources almost nullifies the coefficients related to SSE positions. The higher conflict perceived by selfemployed with employees, genuine SSE, and dependent SSE is connected both to their more demanding job conditions in terms of time, pace of work, emotional and cognitive pressures, and to their job-related resources, especially working from home and having high control on working time - which fuel the perception of conflict instead of mitigate it.

In the case of women, job demands and resources considered in the models are not able to nullify the differences in the perception of work-family conflict across different work arrangements. Model 4 shows that - after controlling for job demands and resources the self-employed with employees and genuine SSE continue to face significative higher levels of work-family conflict with respect to dependent SSE, employees and informal workers. For women, therefore, higher responsibilities and authority for their business, typical of genuine forms of self-employment, is a source of conflict that are 
not cancelled by other job-related factors considered in the analyses.

\section{Self-employment and work-family conflict: The role of national gender context}

To examine the role of contextual variables in moderating the experience of conflict of men and women in different work arrangements, we took model 4 shown in Table 3 and re-estimated it by separately adding each of the four macro institutional and societal indicators included in our dataset and a cross-level interactions between each macro indicators and the work arrangements. Table 4 reports selected coefficients from the models estimated for each macro indicator.

$* * * * *$ Tables $4 * * * * *$

The results illustrate that the coefficients related to the availability of family policies do not influence our measure of subjective work-family conflict. Rather, it is connected to gender norms and actual gender (a)symmetries in the labour market, and, only for women, to the labour market structure. These factors are correlated to country-based differences in the perception of work-family conflict across work arrangements.

The interactions between the labour market structure index and the work arrangements suggest that, only in the case of women, the gap between self-employed and employees' perception of work-family conflict is relevant where work-life balance policies are weak and the barriers to labour market access are high. Vice versa, the work-family conflict of SE with employees and SSE women (both genuine and dependent) is limited and tends to correspond with the one of employees in more open labour markets.

Focusing on societal factors, both in the case of the gender norms index and the gender 
equality index, the interactions between the two macro societal indexes with the work arrangements suggest that these average trends vary considerably between selfemployment types, dependent employment and informal work, both among men and among women.

To provide a more exhaustive picture of the role of societal contextual factors, we have depicted in four graphs the values predicted by the estimated models in tables 4 for men and women by work arrangements (Figures 2 and 3). These figures allow to visualize how work-family conflict is perceived by different categories of workers according to the level of gender norms and gender equality achieved in the labour market. The representation of predicted values substantially changes for women and men in different work arrangements.

$* * * * *$ Figure 2 and Figure 3 about here*******

In the case of women, both contextual gender norms (Figure 2) and gender equality in the labour market (Figure 3) play a strong role in the self-employed workers' perception of work-family conflict. The experience of conflict by self-employed with employees and genuine SSE is particularly high in contexts where traditional norms prevail and gender asymmetries in the labour market are wide, while it converges to the level of dependent SSE and employees in more gender egalitarian contexts, where gender roles are more blurred. In traditional contexts, dependent SSE women perceive higher levels of work-family conflict than employees and informal workers, but lower than other selfemployed workers. For dependent SSE - as well as employees (both permanent and fixed-term) - the slope is less pronounced, thus the changes of work-family conflict due to contextual levels of gender norms and labour market equality levels are less marked. Overall, the picture suggests that being a genuine self-employed woman in countries 
that are more gender-conservative and in unequal labour markets is correlated with higher experiences of conflict. This gap disappears in more egalitarian contexts.

In the case of men the distances between work arrangements are less noticeable. As in the case of women, in gender traditional contexts, and in labour markets with limited gender equality, self-employed with employees and genuine SSE perceive higher levels of work-family conflict than employees (both fixed-term and permanent) and informal workers. Where the levels of gender equality in society and the labour market are higher, the perception of work-family conflict of self-employed workers with employees and genuine SSE decreases and is similar to that of employees.

\section{Discussion and conclusions}

This study contributes to the debate on how the self-employed balance conflicted pressures between work and family in two ways. Firstly, by adopting a more detailed classification of self-employment - based on the level of economic independence in managing the business - we are able to take into consideration the heterogeneity of selfemployment and how it can differently affect the perception of work-family conflict. Secondly, assuming that subjective work-family conflict is institutional embedded, we show how gender-related institutional and societal factors modulate the experience of conflict for different types of self-employed workers.

Considering the heterogeneity of positions within self-employment, it has been decisive to catch the variations in the subjective experiences of conflict. In fact, our findings show that the perception of work-family conflict varies consistently across selfemployment types. At the micro level, the differences across work arrangements are mainly connected to variations in the levels of job-related demands associated to 
different positions. Despite the highest availability of autonomy and control over their job conditions, workers actually self-employed - i.e. the self-employed with employees and genuine SSE - share such overwhelming job demands (job pressures, responsibilities and commitment over their business), that they end up increasing the perception of work-family conflict. Only dependent SSE, with job-related demands and job-related resources closer to those of employees, perceive a lower conflict, reaching levels of subjective work-family conflict similar to those of employees.

Our findings are then in line with the body of the literature that stresses the role of the demands related to self-employment - mainly high job involvement and time commitment - which favour a perception of conflict that is not counter-balanced by the available job-resources (Annink \& den Dulk, 2012; König \& Cesinger, 2015; Parasuraman \& Simmers, 2001).

The role of job-related resources is instead ambivalent. In fact, resources such as autonomy and control on when, where and how to work have a limited power in counteract job-related time, task and work-load pressures. And, as in the case of who work prevalently from home - prevalent among self-employed - they fuel the subjective conflict. Therefore, higher control, autonomy and flexibility over a job position can favour the inclusion in the labour market lowering the tensions between work and private pressures. But they do not mediate the daily experience of conflict in the way suggested by the studies that interpret self-employment mainly as a resource. Quite the contrary, these resources can make the daily boundaries between work and private life even blurrier, especially in the case of the self-employed - with negative consequences on the subjective work-life balance (Hilbrecht \& Lero, 2014).

At the macro level, our findings point out that the national gender context represents a crucial analytical dimension for understanding the relationship between working 
arrangements and subjective work-family conflict. The actual level of gender equality available in society and in the labour market, are factors that catch substantial variations across countries and working arrangements.

While the average level of work-family conflict of dependent SSE in different contexts almost overlaps with those of employees, among the self-employed with employees and genuine SSE the subjective conflict varies substantially, moving from a gender traditional context to an egalitarian one. In fact, workers who are actually self-employed perceive the highest levels of conflict in gender traditional countries. Their distance from all other work arrangements in these contexts is significant, and this divide is accentuated among women. This result can be traced back to the prevalence and reproduction of masculine norms and gender unequal job conditions typical of traditional contexts, which exacerbate conflictual circumstances within and between work and private spheres (Powell et al., 2009).

From a gender perspective, differences among women reflect more closely the levels of gender equality accessible and achieved in the labour market, whilst differences among men reflect more contextual differences in gender norms in society. For women, to be a worker in traditional contexts is somewhat norm-breaking (Hagqvist, Gådin, \& Nordenmark, 2017), and women who are self-employed with employees and genuine SSE are even more ground-breaking than dependent SSE and employees, especially if we take into account the prevalent masculine culture that permeates business activities (Bruni et al., 2004; Clark Muntean \& Ozkazanc-Pan, 2015). For men - among whom the gaps between jobs are much less pronounced - the prevalence of a traditional gender model in society basically implies the reproduction of the traditional breadwinner model. Thus, men working as self-employed with employees and genuine SSE - who are more exposed to business risk and economic instability - exhibit a greater 
perception of work-family conflict compared to dependent SSE and employees. Both for women and for men, the gap with other work arrangements reduced in more gender egalitarian contexts, where the distribution of (paid and unpaid) work is less gendered and the differences are more related to individual job-related conditions.

In conclusion, self-employment positions in Europe are not an easy way to include more workers in the labour market favouring work-life balance over the life course. Our study ultimately suggests that the implications may differ depending on the type of selfemployment and on the level of gender egalitarism shared in a society.

On the one side, the development of genuine forms of self-employment could produce a general growth of the levels of subjective work-family conflict because of the predominant role of job-related demands connected to these positions on the perception of conflict. And this increase could be even stronger in gender traditional and conservative countries. A traditional gender culture, in fact, disadvantages genuine forms of entrepreneurship more than any other employment relationship. Thus, the expansion of entrepreneurial positions has to go hand in hand with the development of policies that actively counteract unequal gender cultures in societies and gender gaps in the labour markets. In particular, the availability of gender-equality policies affect the subjective conflict of (women) self-employed and favour the consolidation of gender egalitarian societies.

On the other side, dependent SSE seem to more effectively limit the perception of workfamily conflict and to be more able to limit the demands connected to job circumstances and to access more flexible working conditions, especially in the case of women. However, this is not without costs. Dependent SSE are weak job positions that largely derive from the spread of outsourcing and sub-contracting practices aimed at reducing labour costs. They are almost excluded by the labour and social protection systems, 
which form the basis of a marginalization process of the workforce (Smeaton, 2003, Eurofound, 2017, Williams \& Horodnic, 2018).

\section{References}

Abendroth, A. K., \& den Dulk, L. (2011). Support for the work-life balance in europe: The impact of state, workplace and family support on work-life balance satisfaction. Work, Employment and Society, 25(2), 234-256. https://doi.org/10.1177/0950017011398892

Annink, A., \& den Dulk, L. (2012). Autonomy: the panacea for self-employed women's work-life balance? Community, Work \& Family, 15(4), 383-402. https://doi.org/10.1080/13668803.2012.723901

Annink, A., den Dulk, L., \& Steijn, B. (2016). Work-Family Conflict Among Employees and the Self-Employed Across Europe. Social Indicators Research, 126(2), 571-593. https://doi.org/10.1007/s11205-015-0899-4

Bianchi, S. M., \& Milkie, M. A. (2010). Work and Family Research in the First Decade of the 21st Century. Journal of Marriage and Family, 72(3), 705-725. https://doi.org/10.1111/j.1741-3737.2010.00726.x

Bruni A, Gherardi S, \& Poggio B. (2004). Doing Gender, Doing Entrepreneurship: An Ethnographic Account of Intertwined Practices. Gender, Work and Organization, 11(4), 406-429.

Buschoff, K. S., \& Schmidt, C. (2009). Adapting labour law and social security to the needs of the "new self-employed" -- comparing the UK, Germany and the Netherlands. Journal of European Social Policy, 19(2), 147-159. https://doi.org/10.1177/0958928708101867 
Chung, H. (2011). Work-Family Conflict across 28 European Countries: A Multi-level Approach. In Work-Life Balance in Europe (pp. 42-68). Palgrave Macmillan, London. https://doi.org/10.1057/9780230307582_3

Clark Muntean, S., \& Ozkazanc-Pan, B. (2015). A Gender Integrative Theory of Entrepreneurship. New England Journal of Entrepreneurship, 18(1), 1-14. https://doi.org/10.5465/ambpp.2014.15508abstract

Cousins, C. R., \& Tang, N. (2004). Working time and work and family conflict in the Netherlands, Sweden and the UK. Work, Employment and Society, 18(3), 531-549. https://doi.org/10.1177/0950017004045549

Dekker, F. (2010). Self-Employed without Employees: Managing Risks in Modern Capitalism. Politics \& Policy (Vol. 38). Published by Wiley Periodicals, Inc. Eurofound. (2017). Exploring self-employment in the European Union (EF). Luxembourg: Publications Office of the European Union.

Eurofound . (2017). European Working Conditions Survey, 2015. [data collection]. 4th Edition. UK Data Service. SN: 8098, http://doi.org/10.5255/UKDA-SN-8098-4 Fahlén, S. (2014). Does gender matter? Policies, norms and the gender gap in work-tohome and home-to-work conflict across Europe. Community, Work and Family, 17(4), 371-391. https://doi.org/10.1080/13668803.2014.899486

Gallie, D., \& Russell, H. (2009). Work-family conflict and working conditions in Western Europe. Social Indicators Research, 93(3), 445-467. https://doi.org/10.1007/s11205-008-9435-0

Georgellis, Y., \& Wall, H. J. (2005). Gender differences in self-employment. International Review of Applied Economics, 19(3), 321-342. https://doi.org/10.1080/02692170500119854

Gherardi, S., \& Poggio, B. (2018). Beyond the gender-neutral approach Gender and 
entrepreneurship as an intertwined social practice. In S. Y. Yousafzi, A. Lindgreen, S. Saeed, \& C. Henry (Eds.), Contextual Embeddedness of Women's

Entrepreneurship. Going Beyond a Gender Neutral Approach (pp. 272-284).

London: Routledge.

Goode, W. J. (1960). A Theory of Role Strain. American Sociological Review, 25(4), 483-496. https://doi.org/10.1017/S0001972000079572

Hagqvist, E., Gådin, K. G., \& Nordenmark, M. (2017). Work-Family Conflict and Well-Being Across Europe: The Role of Gender Context. Social Indicators Research, 132(2), 785-797. https://doi.org/10.1007/s11205-016-1301-x

Hagqvist, E., Toivanen, S., \& Bernhard-Oettel, C. (2018). Balancing Work and Life When Self-Employed: The Role of Business Characteristics, Time Demands, and Gender Contexts. Social Sciences, 7(8), 139. https://doi.org/10.3390/socsci7080139

Hagqvist, E., Toivanen, S., \& Vinberg, S. (2015). Time strain among employed and self-employed women and men in Sweden. Society, Health \& Vulnerability, 6(1), 29183. https://doi.org/10.3402/shv.v6.29183

Hilbrecht, M., \& Lero, D. S. (2014). Self-employment and family life: constructing work-life balance when you're 'always on.' Community, Work \& Family, 17(1), 20-42. https://doi.org/10.1080/13668803.2013.862214

König, S., \& Cesinger, B. (2015). Gendered work-family conflict in Germany: do selfemployment and flexibility matter? Work, Employment and Society, 29(4), 531549. https://doi.org/10.1177/0950017014545264

Kossek, E. E., \& Lee, K.-H. (2017). Work-Family Conflict and Work-Life Conflict. In Oxford Research Encyclopedia, Business and Management (Vol. 1, pp. 1-23). https://doi.org/10.1093/acrefore/9780190224851.013.52 
Matysiak, A., \& Węziak-Białowolska, D. (2016). Country-Specific Conditions for Work and Family Reconciliation: An Attempt at Quantification. European Journal of Population, 32(4), 475-510. https://doi.org/10.1007/s10680-015-9366-9

McGinnity, F., \& Whelan, C. T. (2009). Comparing Work-Life Conflict in Europe:

Evidence from the European Social Survey. Social Indicators Research. https://doi.org/10.1007/s11205-008-9437-y

Nordenmark, M., Vinberg, S., \& Strandh, M. (2012). Job control and demands, worklife balance and wellbeing among self-employed men and women in Europe. Vulnerable Groups \& Inclusion. https://doi.org/10.3402/vgi.v3i0.18896

Ollier-Malaterre, A., \& Foucreault, A. (2016). Cross-National Work-Life Research. Journal of Management, 43(1), 111-136.

https://doi.org/10.1177/0149206316655873

Parasuraman, S., \& Simmers, C. A. (2001). Type of employment, work-family conflict and well-being: a comparative study. Journal of Organizational Behavior, 22(5), 551-568. https://doi.org/10.1002/job.102

Powell, G. N., Francesco, A. M., \& Ling, Y. (2009). Toward culture-sensitive theories of the work-family interface. Journal of Organizational Behavior, 30(5), 597-616. https://doi.org/10.1002/job.568

Reynolds, J., \& Renzulli, L. A. (2005). Economic Freedom or Self-imposed Strife: Work-Life Conflict, Gender, and Self-Employment. In Research in the Sociology of Work (Vol. 15, pp. 33-60). Bingley: Emerald (MCB UP ). https://doi.org/10.1016/S0277-2833(05)15003-1

Ruppanner, L., \& Huffman, M. L. (2014). Blurred Boundaries: Gender and WorkFamily Interference in Cross-National Context. Work and Occupations, 41(2), 210-236. https://doi.org/10.1177/0730888413500679 
Russell, H., O'Connell, P. J., \& McGinnity, F. (2009). The impact of flexible working arrangements on work-life conflict and work pressure in Ireland. Gender, Work and Organization, 16(1), 73-97. https://doi.org/10.1111/j.1468-0432.2008.00431.x

Schieman, S., Glavin, P., \& Milkie, M. A. (2009). When Work Interferes with Life: Work-Nonwork Interference and the Influence of Work-Related Demands and Resources. American Sociological Review, 74(6), 966-988.

https://doi.org/10.1177/000312240907400606

Smeaton, D. (2003). Self-Employed Workers: Calling the Shots or Hesitant Independents? A Consideration of the Trends. Work, Employment and Society, 17(2), 379-391. https://doi.org/10.1177/0950017003017002008

Steiber, N. (2009). Reported levels of time-based and strain-based conflict between work and family roles in Europe: A multilevel approach. Social Indicators Research, 93(3), 469-488. https://doi.org/10.1007/s11205-008-9436-z

van der Lippe, T., Jager, A., \& Kops, Y. (2006). Combination Pressure: The Paid WorkFamily Balance of Men and Women in European Countries. Acta Sociologica, 49(3), 303-319. https://doi.org/10.1177/0001699306067711

Williams, C., \& Horodnic, I. A. (2018). Evaluating the Prevalence and Distribution of Dependent Self-Employment: Some Lessons from the European Working Conditions Survey. Industrial Relations JOunal, 49(2), 109-127. https://doi.org/10.1111/irj.12206 


\section{Tables}

Table 1. Job related resources by working arrangements and sex

\begin{tabular}{|c|c|c|c|c|c|c|c|}
\hline & \multicolumn{7}{|c|}{ Men } \\
\hline & $\begin{array}{c}\text { SE with } \\
\text { employees }\end{array}$ & $\begin{array}{c}\text { Genuine } \\
\text { SSE } \\
\end{array}$ & $\begin{array}{c}\text { Dependent } \\
\text { SSE } \\
\end{array}$ & Permanent & Fixed term & Informal & All \\
\hline \multicolumn{8}{|l|}{ Working schedule controlfflexibility } \\
\hline - Flexibility fixed by the org. & $3.0 \%$ & $3.6 \%$ & $5.0 \%$ & $9.3 \%$ & $7.7 \%$ & $5.5 \%$ & $8.0 \%$ \\
\hline - Worker can choose (flextime) & $11.4 \%$ & $9.8 \%$ & $18.5 \%$ & $20.7 \%$ & $15.3 \%$ & $17.1 \%$ & $18.7 \%$ \\
\hline - Complete control & $75.0 \%$ & $83.1 \%$ & $61.7 \%$ & $6.0 \%$ & $4.2 \%$ & $19.1 \%$ & $18.2 \%$ \\
\hline Working from home & $41.0 \%$ & $42.6 \%$ & $38.1 \%$ & $12.8 \%$ & $8.7 \%$ & $14.3 \%$ & $17.4 \%$ \\
\hline Commuting (hours per week) & $2.6 \mathrm{~h}$. & $2.2 \mathrm{~h}$. & $2.5 \mathrm{~h}$. & $3.7 \mathrm{~h}$. & $3.4 \mathrm{~h}$. & $2.7 \mathrm{~h}$. & $3.4 \mathrm{~h}$. \\
\hline \multicolumn{8}{|l|}{ Discretion on: } \\
\hline - Tasks $(\%)$ & $92.3 \%$ & $92.8 \%$ & $77.0 \%$ & $63.6 \%$ & $53.9 \%$ & $59.7 \%$ & $66.6 \%$ \\
\hline - Method of work (\%) & $92.0 \%$ & $92.7 \%$ & $82.8 \%$ & $66.7 \%$ & $55.4 \%$ & $62.5 \%$ & $69.3 \%$ \\
\hline - Speed $(\%)$ & $91.6 \%$ & $94.5 \%$ & $82.0 \%$ & $68.2 \%$ & $62.5 \%$ & $68.4 \%$ & $71.4 \%$ \\
\hline Job autonomy (std. index) & 0.818 & 0.684 & 0.313 & -0.061 & -0.296 & -0.242 & 0.026 \\
\hline Well paid job (perception) (\%) & $55.3 \%$ & $46.7 \%$ & $47.7 \%$ & $51.9 \%$ & $46.0 \%$ & $40.6 \%$ & $50.6 \%$ \\
\hline Job security (perception) (\%) & $92.8 \%$ & $90.5 \%$ & $86.9 \%$ & $89.2 \%$ & $62.0 \%$ & $77.4 \%$ & $86.0 \%$ \\
\hline \multirow[t]{3}{*}{ High skilled job (\%) } & $48.9 \%$ & $40.7 \%$ & $38.4 \%$ & $38.0 \%$ & $26.7 \%$ & $17.5 \%$ & $37.0 \%$ \\
\hline & \multicolumn{7}{|c|}{ Women } \\
\hline & $\begin{array}{c}\text { SE with } \\
\text { employees }\end{array}$ & $\begin{array}{c}\text { Genuine } \\
\text { SSE }\end{array}$ & $\begin{array}{l}\text { Dependent } \\
\text { SSE }\end{array}$ & Permanent & Fixed term & Informal & All \\
\hline \multicolumn{8}{|l|}{ Working schedule control/flexibility } \\
\hline - Flexibility fixed by the organization & $4.6 \%$ & $2.1 \%$ & $4.8 \%$ & $11.1 \%$ & $10.9 \%$ & $4.0 \%$ & $10.0 \%$ \\
\hline - Worker can choose (flextime) & $10.5 \%$ & $10.2 \%$ & $15.9 \%$ & $20.5 \%$ & $15.5 \%$ & $20.6 \%$ & $18.9 \%$ \\
\hline - Complete control & $69.8 \%$ & $82.1 \%$ & $69.7 \%$ & $4.4 \%$ & $5.1 \%$ & $19.5 \%$ & $12.2 \% \mathrm{~W}$ \\
\hline Working from home & $33.2 \%$ & $46.9 \%$ & $51.7 \%$ & $13.1 \%$ & $12.0 \%$ & $17.6 \%$ & $16.5 \%$ \\
\hline Commuting (hours per week) & $1.7 \mathrm{~h}$. & $1.7 \mathrm{~h}$. & $1.6 \mathrm{~h}$. & $3.2 \mathrm{~h}$. & $2.9 \mathrm{~h}$. & $1.7 \mathrm{~h}$. & $3.0 \mathrm{~h}$. \\
\hline \multicolumn{8}{|l|}{ Discretion on: } \\
\hline - Tasks $(\%)$ & $85.1 \%$ & $95.7 \%$ & $85.4 \%$ & $67.9 \%$ & $60.2 \%$ & $68.1 \%$ & $69.1 \%$ \\
\hline - Method of work (\%) & $88.2 \%$ & $93.3 \%$ & $86.6 \%$ & $68.5 \%$ & $56.6 \%$ & $69.5 \%$ & $69.1 \%$ \\
\hline - Speed (\%) & $81.0 \%$ & $91.2 \%$ & $87.4 \%$ & $69.4 \%$ & $61.9 \%$ & $71.9 \%$ & $70.3 \%$ \\
\hline Job autonomy (std. index) & 0.830 & 0.711 & 0.256 & -0.082 & -0.372 & -0.328 & -0.065 \\
\hline Well paid job (perception) (\%) & $54.7 \%$ & $46.9 \%$ & $40.3 \%$ & $50.3 \%$ & $46.8 \%$ & $44.1 \%$ & $49.2 \%$ \\
\hline Job security (perception) (\%) & $93.2 \%$ & $90.1 \%$ & $87.0 \%$ & $90.9 \%$ & $48.9 \%$ & $88.9 \%$ & $95.9 \%$ \\
\hline High skilled job (\%) & $58.4 \%$ & $48.6 \%$ & $37.5 \%$ & $45.5 \%$ & $32.7 \%$ & $12.5 \%$ & $42.6 \%$ \\
\hline
\end{tabular}

Note: Weighted values 
Table 2. Job related demands by working arrangements and sex (EU27)

\begin{tabular}{|c|c|c|c|c|c|c|c|}
\hline & \multicolumn{7}{|c|}{ Men } \\
\hline & $\begin{array}{l}\text { SE with } \\
\text { employees }\end{array}$ & $\begin{array}{l}\text { Genuine } \\
\text { SSE }\end{array}$ & $\begin{array}{l}\text { Dependent } \\
\text { SSE }\end{array}$ & Permanent & $\begin{array}{l}\text { Fixed } \\
\text { term }\end{array}$ & Informal & All \\
\hline $\begin{array}{l}\text { Weekly working hours } \\
\text { - \% work less than } 25 \\
\text { hours }\end{array}$ & $\begin{array}{l}48.7 \mathrm{~h} . \\
4.3 \%\end{array}$ & $\begin{array}{l}43.8 \mathrm{~h} . \\
12.4 \%\end{array}$ & $\begin{array}{l}39.5 \mathrm{~h} . \\
19.2 \%\end{array}$ & $\begin{array}{c}40.4 \mathrm{~h} . \\
4.7 \%\end{array}$ & $\begin{array}{l}36.9 \mathrm{~h} . \\
17.4 \%\end{array}$ & $\begin{array}{l}33.5 \mathrm{~h} . \\
37.1 \%\end{array}$ & $\begin{array}{l}40.5 \mathrm{~h} . \\
8.4 \%\end{array}$ \\
\hline $\begin{array}{l}\text { - \% work more than } 45 \\
\text { hours }\end{array}$ & $59.2 \%$ & $43.7 \%$ & $32.8 \%$ & $17.6 \%$ & $15.1 \%$ & $20.5 \%$ & $22.4 \%$ \\
\hline $\begin{array}{l}\text { Working schedule } \\
\text { demands (std index) }\end{array}$ & 0.469 & 0.302 & 0.220 & -0.047 & -0.037 & 0.120 & 0.027 \\
\hline $\begin{array}{l}\text { Job pressures: } \\
\text { - Pace demands (std. } \\
\text { index) }\end{array}$ & 0.100 & -0.073 & -0.051 & 0.112 & 0.073 & 0.015 & 0.084 \\
\hline $\begin{array}{l}\text { - Emotional demands } \\
\text { (std. index) }\end{array}$ & 0.092 & -0.011 & -0.100 & -0.142 & -0.247 & -0.167 & -0.130 \\
\hline \multirow[t]{3}{*}{$\begin{array}{l}\text { - Cognitive demands } \\
\text { (std. index) }\end{array}$} & 0.264 & 0.277 & 0.066 & 0.135 & -0.019 & -0.247 & 0.118 \\
\hline & \multicolumn{7}{|c|}{ Women } \\
\hline & $\begin{array}{c}\text { SE with } \\
\text { employees }\end{array}$ & $\begin{array}{l}\text { Genuine } \\
\text { SSE }\end{array}$ & $\begin{array}{c}\text { Dependent } \\
\text { SSE }\end{array}$ & Permanent & $\begin{array}{c}\text { Fixed } \\
\text { term }\end{array}$ & Informal & All \\
\hline Weekly working hours & $43.6 \mathrm{~h}$. & $40.0 \mathrm{~h}$. & 34.4 h. & $34.1 \mathrm{~h}$. & $31.3 \mathrm{~h}$. & $25.8 \mathrm{~h}$. & $33.9 \mathrm{~h}$. \\
\hline $\begin{array}{l}\text { - \% work less than } 25 \\
\text { hours }\end{array}$ & $13.0 \%$ & $17.6 \%$ & $34.8 \%$ & $23.5 \%$ & $35.7 \%$ & $54.8 \%$ & $26.4 \%$ \\
\hline $\begin{array}{l}\text { - \% work more than } 45 \\
\text { hours }\end{array}$ & $43.8 \%$ & $31.7 \%$ & $24.2 \%$ & $7.8 \%$ & $7.8 \%$ & $10.0 \%$ & $9.9 \%$ \\
\hline $\begin{array}{l}\text { Working schedule } \\
\text { demands (std index) }\end{array}$ & 0.276 & 0.219 & 0.081 & -0.168 & -0.106 & -0.116 & -0.122 \\
\hline $\begin{array}{l}\text { Job pressures: } \\
\text { - Pace demands }\end{array}$ & & & & & & & \\
\hline $\begin{array}{l}\text { - Pace demands (std. } \\
\text { index) }\end{array}$ & -0.028 & -0.282 & -0.184 & 0.029 & 0.042 & -0.265 & -0.001 \\
\hline $\begin{array}{l}\text { - Emotional demands } \\
\text { (std. index) }\end{array}$ & 0.198 & 0.155 & -0.115 & 0.107 & 0.084 & -0.167 & 0.088 \\
\hline $\begin{array}{l}\text { - Cognitive demands } \\
\text { (std. index) }\end{array}$ & 0.264 & 0.129 & -0.078 & 0.054 & -0.166 & -0.479 & 0.006 \\
\hline
\end{tabular}

Note: Weighted values 
Table 3. Determinants of subjective work-family conflict. Men and Women EU2. Individual- level factors.

\begin{tabular}{|c|c|c|c|c|c|c|c|c|}
\hline & \multicolumn{4}{|c|}{ Men } & \multicolumn{4}{|c|}{ Women } \\
\hline & M1 & M2 & M3 & M4 & M1 & M2 & M3 & M4 \\
\hline \multicolumn{9}{|l|}{ Work arrangement (Ref: Permanent) } \\
\hline SE with employees & $0.458 * * *$ & $0.322 * * *$ & $0.157 * * *$ & $0.095 * * *$ & $0.424 * * *$ & $0.480 * * *$ & $0.139 * *$ & $0.206^{* * *}$ \\
\hline Genuine SSE & $0.280 * * *$ & $0.121 * *$ & $0.141 * * *$ & 0.053 & $0.306^{* * *}$ & $0.349 * * *$ & $0.183 * *$ & $0.223 * * *$ \\
\hline Dependent SSE & $0.118 * * *$ & -0.020 & 0.063 & -0.015 & 0.045 & 0.061 & 0.049 & 0.064 \\
\hline Fixed-term & -0.065 & $-0.099 * *$ & 0.005 & -0.022 & -0.027 & -0.057 & 0.013 & -0.01 \\
\hline Informal & $-0.159 * *$ & $-0.198 * * *$ & $-0.100 * *$ & $-0.132 * * *$ & $-0.296 * * *$ & $-0.249 * * *$ & $-0.083^{*}$ & $-0.085^{*}$ \\
\hline \multicolumn{9}{|l|}{ Job demands } \\
\hline Weekly Working hours & & & $0.008 * * *$ & $0.008 * * *$ & & & $0.011 * * *$ & $0.009 * * *$ \\
\hline Working schedule demands & & & $0.293 * * *$ & $0.280 * * *$ & & & $0.300 * * *$ & $0.291 * * *$ \\
\hline Pace demands & & & $0.281 * * *$ & $0.269 * * *$ & & & $0.286^{* * *}$ & $0.268 * * *$ \\
\hline Emotional demands & & & $0.195 * * *$ & $0.185^{* * *}$ & & & $0.175 * * *$ & $0.175^{* * *}$ \\
\hline Cognitive demands & & & $0.061 * * *$ & $0.054 * * *$ & & & $0.069 * * *$ & $0.061 * * *$ \\
\hline \multicolumn{9}{|l|}{ Job Resources } \\
\hline \multicolumn{9}{|l|}{$\begin{array}{l}\text { Control over working time } \\
\text { (Ref: Define by the company) }\end{array}$} \\
\hline -choose between fixed working sch. & & $0.144 * * *$ & & $0.046 * *$ & & 0.01 & & -0.024 \\
\hline - adapt working hours & & $0.118 * * *$ & & $0.102 * * *$ & & -0.022 & & 0.021 \\
\hline -entirely determined by self & & $0.183 * * *$ & & $0.130 * * *$ & & $-0.128 * *$ & & $-0.066^{*}$ \\
\hline Working from home & & $0.177 * * *$ & & $0.066^{* *}$ & & $0.210 * * *$ & & $0.094 * *$ \\
\hline Weekly commuting time (hours) & & $0.023 * * *$ & & $0.013 * * *$ & & $0.040 * * *$ & & $0.026 * * *$ \\
\hline Autonomy & & 0.029 & & -0.001 & & $0.043 *$ & & 0.012 \\
\hline Task control: order & & -0.031 & & -0.013 & & $0.033^{*}$ & & 0.035 \\
\hline Task control: method & & $0.066^{*}$ & & $0.048 *$ & & 0.022 & & 0.029 \\
\hline Task control: speed & & $-0.108 * * *$ & & -0.031 & & $-0.098 * * *$ & & -0.026 \\
\hline Well-paid job (perception) & & $-0.212 * * *$ & & $-0.122 * * *$ & & $-0.268 * * *$ & & $-0.124 * * *$ \\
\hline Job security (perception) & & $-0.175^{* * *}$ & & $-0.114 * * *$ & & $-0.141 * * *$ & & $-0.089 * * *$ \\
\hline High skill job & & 0.03 & & 0.006 & & 0.059 & & -0.008 \\
\hline Agriculture & & 0.047 & 0.074 & 0.064 & & 0.064 & 0.017 & 0.030 \\
\hline \multicolumn{9}{|l|}{ HH characteristics } \\
\hline Having a partner & $0.133 * * *$ & $0.143 * * *$ & $0.118 * * *$ & $0.124 * * *$ & 0.036 & 0.031 & $0.056^{*}$ & $0.053^{*}$ \\
\hline Dependent children & 0.029 & 0.019 & 0.052 & 0.045 & 0.021 & 0.039 & $0.076^{* *}$ & $0.083 * *$ \\
\hline
\end{tabular}




\begin{tabular}{|c|c|c|c|c|c|c|c|c|}
\hline Caring on daily weekly base & $0.071 *$ & $0.070^{*}$ & $0.058 *$ & $0.060 *$ & 0.086 & $0.096^{*}$ & $0.095 * *$ & $0.098 * *$ \\
\hline $\mathrm{HH}$ economic insecurity & $0.229 * * *$ & $0.180 * * *$ & $0.162 * * *$ & $0.136 * * *$ & $0.193 * * *$ & $0.125 * * *$ & $0.130 * * *$ & $0.099 * * *$ \\
\hline Age & $0.044 * * *$ & $0.039 * * *$ & $0.022 * *$ & $0.020 * *$ & 0.015 & 0.007 & 0.002 & -0.001 \\
\hline Age squared & $-0.001 * * *$ & $-0.000 * * *$ & $-0.000 * *$ & $-0.000 * *$ & 0.000 & 0.000 & 0.000 & 0.000 \\
\hline Tertiary education & $0.126 * * *$ & $0.053^{*}$ & 0.053 & 0.021 & $0.200 * * *$ & $0.098 * * *$ & $0.093 * * *$ & $0.058 *$ \\
\hline Constant & $-1.125^{* * *}$ & $-0.812 * * *$ & $-0.727 * * *$ & $-0.579 * * *$ & $-0.508 * * *$ & -0.151 & -0.244 & -0.130 \\
\hline \multicolumn{9}{|l|}{ Random part } \\
\hline Variance level 2 (Country) & $0.014 * * *$ & $0.014 * * *$ & $0.009 * * *$ & $0.009 * * *$ & $0.021 * * *$ & $0.017 * * *$ & $0.010 * * *$ & $0.010 * * *$ \\
\hline Variance level 1 (Workers) & $0.546 * * *$ & $0.518 * * *$ & $0.398 * * *$ & $0.390 * * *$ & $0.565 * * *$ & $0.525 * * *$ & $0.400 * * *$ & $0.390 * * *$ \\
\hline $\mathrm{ICC}$ & $2.6 \%$ & $2.5 \%$ & $2.2 \%$ & $2.2 \%$ & $3.5 \%$ & $3.1 \%$ & $2.6 \%$ & $2.3 \% * * *$ \\
\hline R squared (Individual level) & $8.6 \%$ & $13.4 \%$ & $33.6 \%$ & $35.1 \%$ & $5.6 \%$ & $12.6 \%$ & $33.8 \%$ & $35.6 \%$ \\
\hline R squared (Country level) & $14.9 \%$ & $19.7 \%$ & $47.3 \%$ & $49.0 \%$ & $12.5 \%$ & $28.7 \%$ & $54.0 \%$ & $59.7 \%$ \\
\hline $\mathrm{N}$ & 15838 & 15838 & 15838 & 15838 & 16480 & 16480 & 16480 & 16480 \\
\hline Countries & 27 & 27 & 27 & 27 & 27 & 27 & 27 & 27 \\
\hline $\mathrm{BIC}$ & 37869.3 & 37081.7 & 32600.2 & 32338.2 & 35494.0 & 34488.2 & 30177.5 & 29878.0 \\
\hline
\end{tabular}

Notes: $* \mathrm{p}<0.05, * * \mathrm{p}<0.01, * * * \mathrm{p}<0.001$. Weighted values 
Table 4 Determinants of subjective work-family conflict. Macro-level factors Men and women, EU27. Multilevel models, selected coefficients

\begin{tabular}{|c|c|c|c|c|c|c|c|c|}
\hline \multirow[b]{2}{*}{ Country-level factors $(M A C R O)$ : } & \multicolumn{4}{|c|}{ Men } & \multicolumn{4}{|c|}{ Women } \\
\hline & $\begin{array}{l}\text { (a) Family } \\
\text { policy index }\end{array}$ & $\begin{array}{l}\text { (b) Labour } \\
\text { market index }\end{array}$ & $\begin{array}{l}\text { (c) Gender } \\
\text { norms } \\
\text { index }\end{array}$ & $\begin{array}{c}\text { (d) Gender } \\
\text { equality } \\
\text { index }\end{array}$ & $\begin{array}{c}\text { (a) Family } \\
\text { policy } \\
\text { index }\end{array}$ & $\begin{array}{l}\text { (b) Labour } \\
\text { market index }\end{array}$ & $\begin{array}{l}\text { (c) Gender } \\
\text { norms index }\end{array}$ & $\begin{array}{l}\text { (d) Gender } \\
\text { equality } \\
\text { index }\end{array}$ \\
\hline \multicolumn{9}{|l|}{ Work arrangement (Ref: Permanent) } \\
\hline SE with employees & 0.011 & 0.193 & $0.195^{*}$ & $0.971 * * *$ & 0.014 & $0.331 *$ & $0.410 * *$ & $1.282 * *$ \\
\hline Genuine SSE & 0.125 & -0.011 & $0.155^{* *}$ & $0.691 * * *$ & 0.097 & $0.517 * *$ & $0.432 * * *$ & $1.296 * * *$ \\
\hline Dependent SSE & 0.071 & -0.074 & $-0.161 * *$ & -0.556 & -0.079 & $0.384 * * *$ & 0.094 & 0.671 \\
\hline Fixed-term & -0.052 & 0.01 & -0.033 & -0.113 & 0.113 & $-0.252 * * *$ & 0.014 & $-0.582 * *$ \\
\hline Informal & -0.151 & -0.094 & $-0.187 *$ & $-1.061 *$ & -0.073 & 0.066 & 0.074 & 0.249 \\
\hline$M A C R O$ & 0.001 & -0.001 & $-0.009 * *$ & $-8.759 *$ & 0.003 & -0.002 & -0.004 & $-11.104^{*}$ \\
\hline MACRO squared & 0.00001 & 0.00001 & $0.001 * *$ & $6.387^{*}$ & 0.00001 & 0.00001 & $0.001 *$ & $7.995^{*}$ \\
\hline \multicolumn{9}{|l|}{ Interactions } \\
\hline SE with empl.* MACRO & 0.003 & -0.002 & -0.002 & $-1.301 * * *$ & 0.006 & -0.002 & $0.001 * *$ & $-1.609 *$ \\
\hline GenuineSSE* MACRO & -0.002 & 0.001 & $-0.002 *$ & $-0.964 * * *$ & 0.004 & $-0.006 * *$ & $-0.004 *$ & $-1.597 * * *$ \\
\hline Dependent SSE* MACRO & -0.003 & 0.001 & $0.003 *$ & 0.807 & 0.005 & $-0.006 * * *$ & -0.001 & -0.904 \\
\hline Fixed-term* $M A C R O$ & 0.001 & -0.001 & 0.000 & 0.133 & -0.004 & $0.005 * * *$ & 0.000 & $0.848 * *$ \\
\hline Informal* $M A C R O$ & 0.001 & -0.001 & 0.001 & $1.378 *$ & 0.000 & -0.003 & $-0.004 *$ & -0.505 \\
\hline Constant & $-0.635 * * *$ & $-0.563 * * *$ & $-0.372 *$ & 2.404 & -0.222 & -0.122 & -0.059 & $3.690 *$ \\
\hline \multicolumn{9}{|l|}{ Random part } \\
\hline Variance level 2 (Country) & 0.008 & 0.001 & 0.007 & 0.008 & 0.009 & 0.009 & 0.008 & 0.008 \\
\hline Variance (Macro) & 0.00001 & 0.00001 & 0.00001 & 0.00001 & 0.00001 & 0.00001 & 0.00001 & 0.00001 \\
\hline Variance level 1 (Workers) & 0.389 & 0.390 & 0.389 & 0.389 & 0.389 & 0.389 & 0.389 & 0.389 \\
\hline R squared (Individual level) & $35.20 \%$ & $35.10 \%$ & $35.39 \%$ & $35.30 \%$ & $35.84 \%$ & $35.91 \%$ & $35.89 \%$ & $36.00 \%$ \\
\hline R squared (Country level) & $51.33 \%$ & $48.28 \%$ & $56.30 \%$ & $52,13 \%$ & $61.64 \%$ & $61.36 \%$ & $63.85 \%$ & $64.53 \%$ \\
\hline $\mathrm{BIC}$ & 32271.1 & 32275.1 & 32259.2 & 32251.6 & 29795.3 & 29774.7 & 29801.4 & 29799.3 \\
\hline $\mathrm{N}$ & 15838 & 15838 & 15838 & 15838 & 16480 & 16480 & 16480 & 16480 \\
\hline Countries & 27 & 27 & 27 & 27 & 27 & 27 & 27 & 27 \\
\hline
\end{tabular}

Notes: $* \mathrm{p}<0.05, * * \mathrm{p}<0.01, * * * \mathrm{p}<0.001$. Other controls: all variables included in the models M4 in Table 3. Weighted values. 


\section{FIGURES}

Figure 1 - Subjective work-family conflict by working arrangement. Men and Women, EU27.
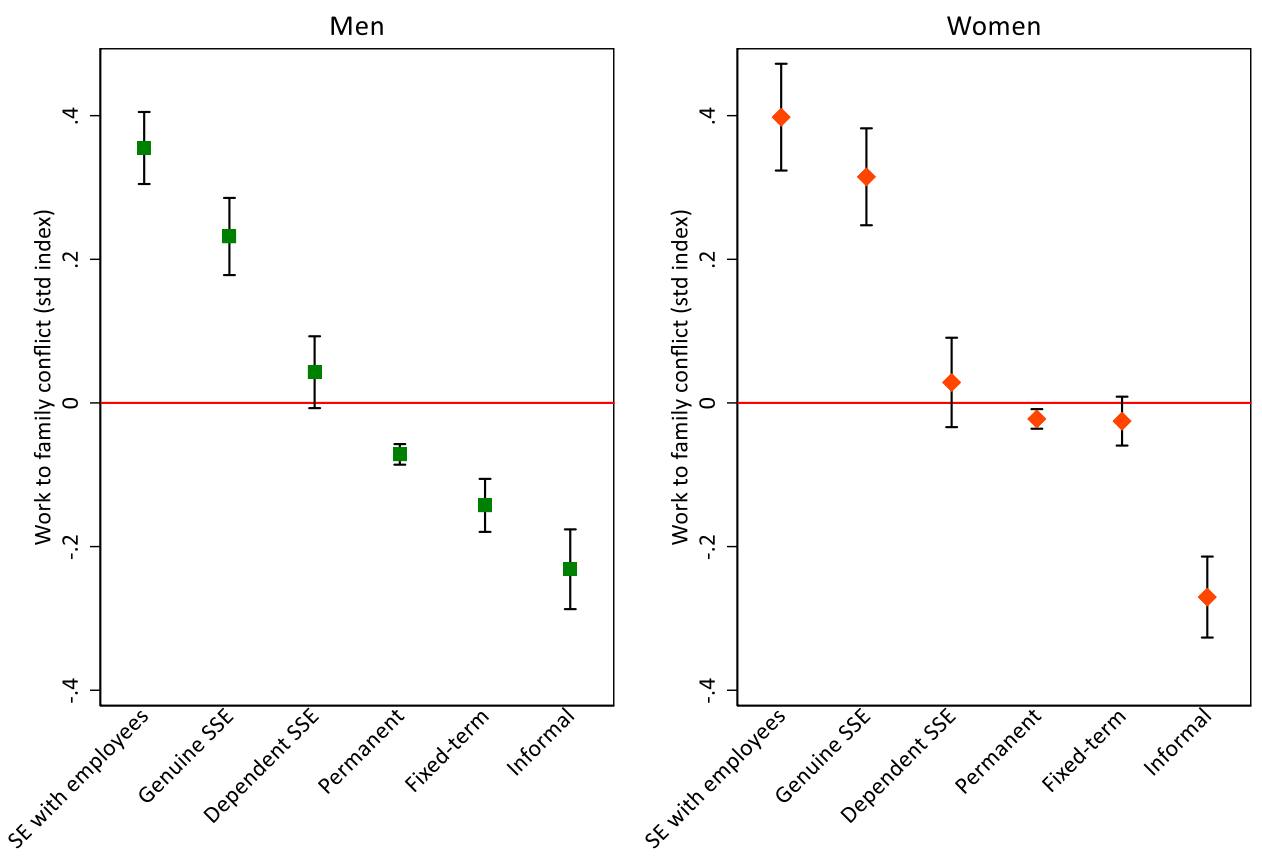
Fig. 2 - Predicted subjective work-family conflict by gender norms index and working arrangements. Predicted values from table 4 columns c).
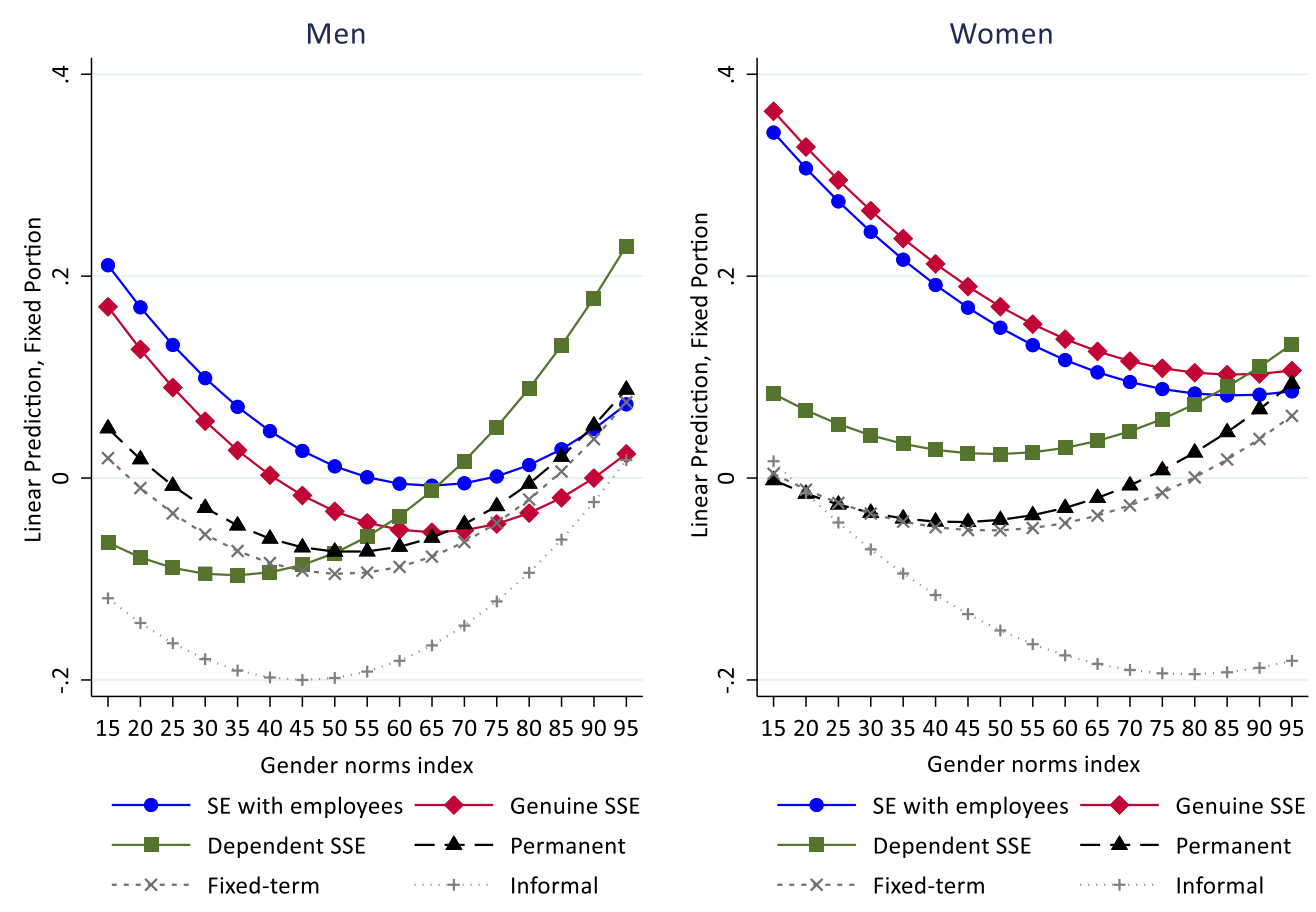
Figure. 3 Predicted subjective work-family conflict by gender equality in the labour market index and working arrangements. Predicted values from table 4 columns d)
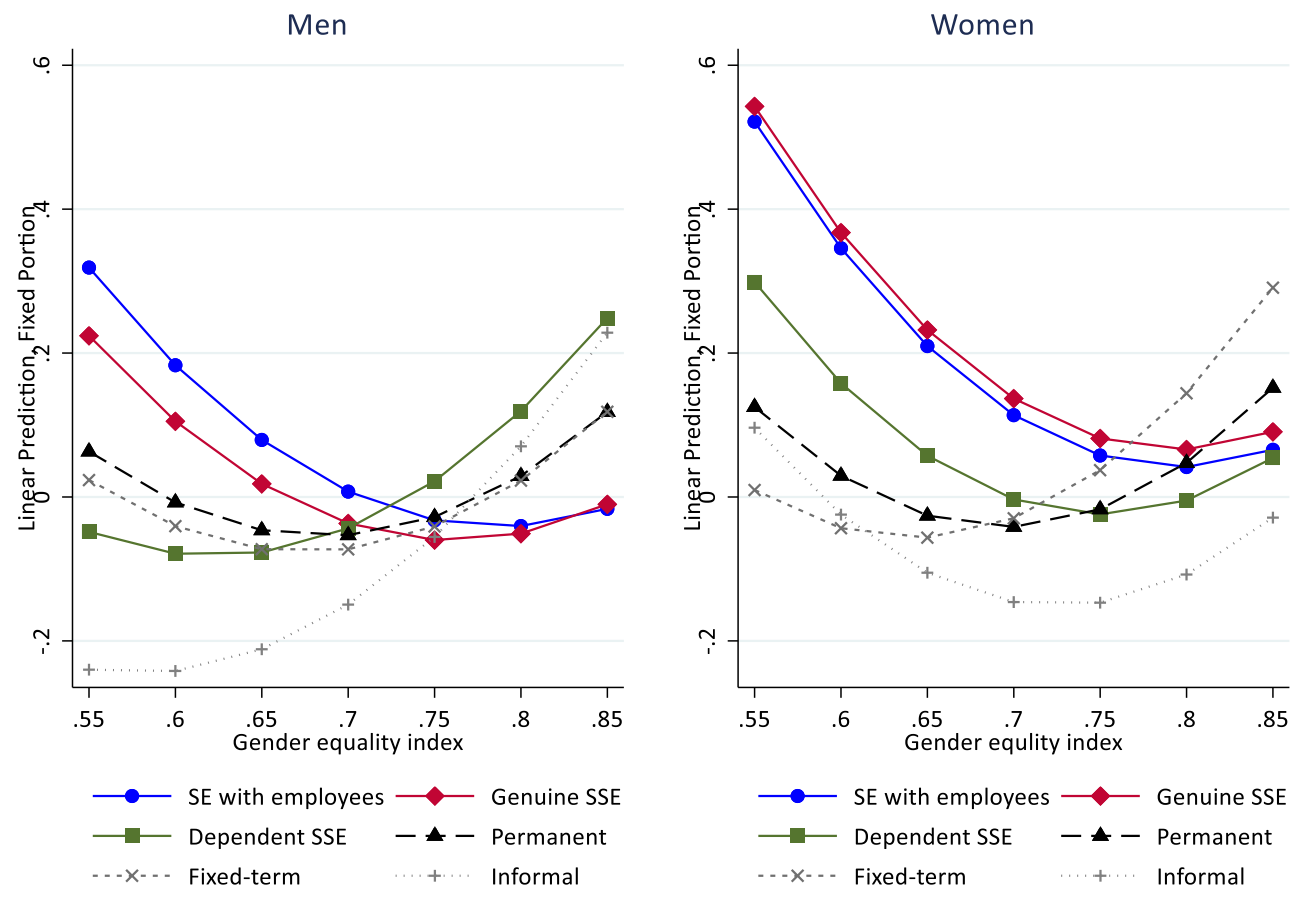